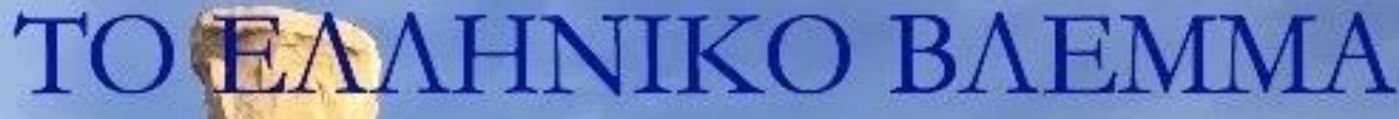

Revista de Estudos Helênicos - UERJ - no. 3 - 2017

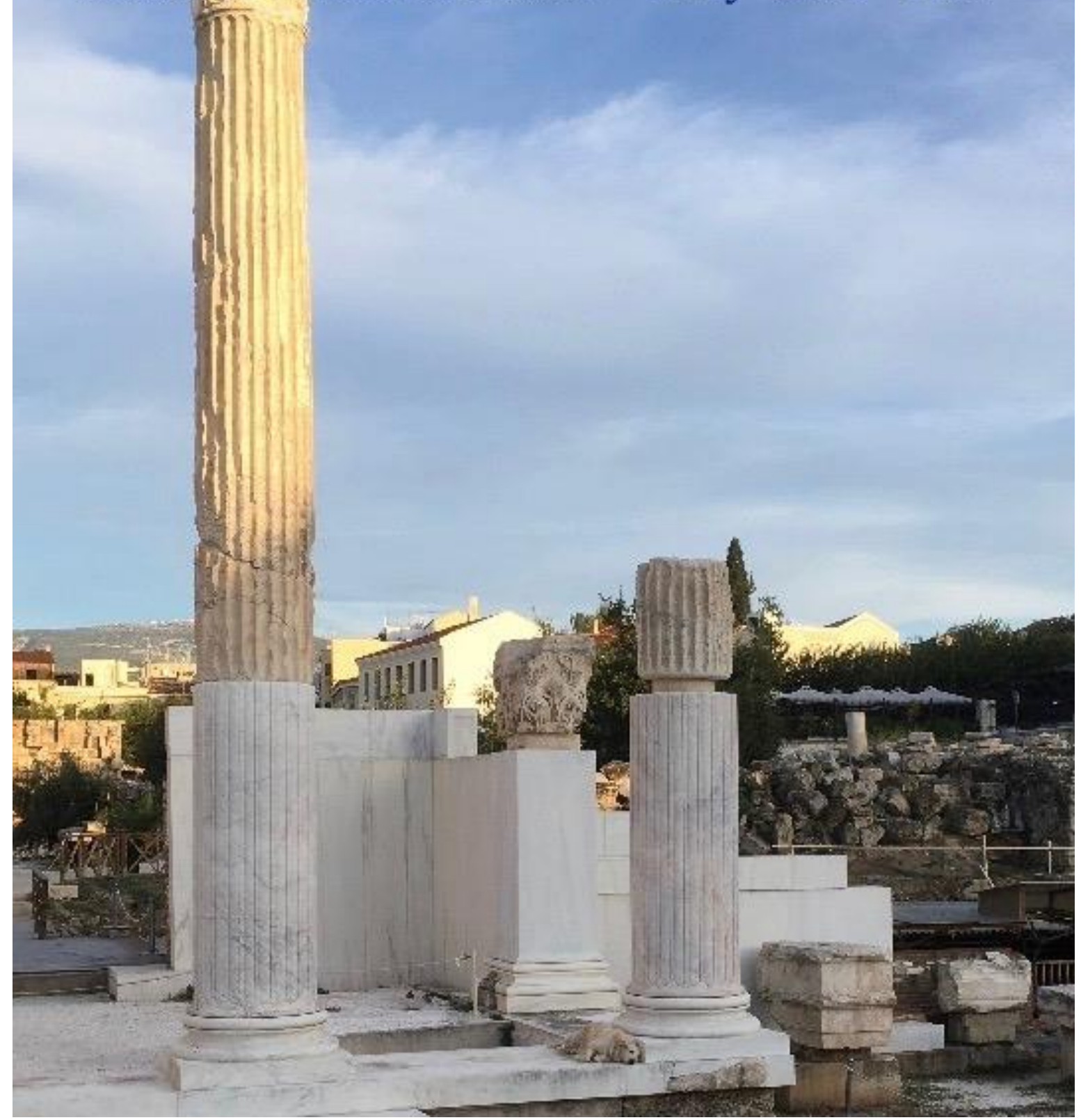




\title{
ENSAIO FILOSÓFICO SOBRE O POEMA DE PARMÊNIDES
}

\author{
Ricardo de Souza Nogueira - PPGLC/UFRJ \\ Zildenice de Souza Martins - PPGLC/UFRJ
}

\section{Resumo}

O presente trabalho foi elaborado com base na pesquisa interdisciplinar que venho desenvolvendo no Curso de Doutorado em Letras Clássicas da UFRJ sob a orientação do Professor Doutor Ricardo de Souza Nogueira. O objetivo deste artigo é identificar algumas características contidas no poema Da Natureza de Parmênides que permitam uma comparação entre a linguagem imagética e simbólica contida em seu proêmio (fragmento 1) e um tipo de expressão mais abstrata, relacionada ao pensamento filosófico-científico, que foi desenvolvido na Grécia a partir do século VI a.C. e que pode ser melhor observado em diversas outras passagens do poema, também selecionadas para constarem nesse estudo (fragmentos 2, 3, 6 e 8). Para isso, o poema será estudado em meio ao contexto de enunciação no qual foi escrito, de modo a identificar as influências recebidas de outros pensadores e constatar os traços das influências da épica e a presença do pensamento filosófico-científico.

Palavras-chave: Parmênides, Poema Da Natureza, Pensamento filosófico

\section{Abstract}

The present paper was prepared on the basis of interdisciplinary research that I have developed in the course of doctorate in Classics of UFRJ under the guidance of Prof. Ricardo de Souza Nogueira. The purpose of this article is to identify some features contained in the poem of Parmenides that allow a comparison between the imagery and symbolic language contained in its proem (fragment 1) and a more abstract expression type, related to philosophical-scientific thought, which was developed in Greece from the 6th century BC and which can be best observed in several other passages of the poem, also selected to appear in this study (fragments 2, 3, 6 and 8). For that, the poem will be studied in the context of utterance in which was written in order to identify the influences received from other thinkers and see the traces of the influence of the epic and the presence of philosophicalscientific thought.

Keys-words: Parmenides, Da Natureza Poem, philosophical thought

A sociedade grega presenciou, principalmente no século VI a.C., a ascensão de homens notáveis que passaram a questionar a validade do tipo de pensamento vigente na época, que associava aos deuses, muito presentes no imaginário grego há séculos, a intervenção nos acontecimentos ordinários da sociedade, utilizando, assim, uma realidade externa para explicar a realidade circundante. Fala-se aqui do pensamento mítico, que obviamente não era produto de uma sociedade supersticiosa ou ignorante, mas sim de pessoas que contavam apenas com esse tipo de pensamento para explicar o real, uma maneira de pensar que ainda creditava aos deuses alguns fenômenos do cotidiano para os quais não se conseguia encontrar explicações simples ou diretas. 
O interesse em compreender a realidade no qual estavam inseridos, buscando uma explicação que não necessariamente incluísse a vontade dos deuses, impulsionou alguns pensadores a criar sistemas filosóficos que contribuíram para, de modo gradual e contínuo, questionar o pensamento mítico característico da época e realizar os primeiros ensaios da ciência que hoje conhecemos como filosofia.

Entre os diversos trabalhos produzidos neste período da história da humanidade, encontra-se o poema Da Natureza, de Parmênides, que, de certa maneira, expressa características dos dois tipos de pensamento existentes, o mítico e o filosófico-científico. O poema foi composto no formato dos poemas épicos, que têm em Homero seu principal representante, a grande diferença que aparece no conteúdo da obra, no entanto, é que os deuses e seres míticos, citados no texto, dividem seu espaço com uma sofisticada reflexão sobre a origem das coisas e sobre o ser e o não-ser em um fascinante exemplo de utilização do pensamento filosóficocientífico, que já se encontrava em pleno desenvolvimento na época.

O poema Da Natureza foi, possivelmente, a única obra composta por Parmênides e seu conteúdo permanece incompleto até o presente momento, pois veio à luz apenas por meio de citações de autores que, de alguma maneira, tiveram contato ou com a obra original ou com partes da mesma. As passagens conservadas desta obra são chamadas de fragmentos, que, na verdade, se constituem de um total de dezenove citações ${ }^{1}$ que pertenciam a um poema em versos hexâmetros de Parmênides. Tais fragmentos foram organizados em uma ordem sequencial por editores que se debruçaram sobre a lógica das ideias que emanavam da obra. ${ }^{2} \mathrm{O}$ fragmento 1, também conhecido como proêmio, foi conservado na íntegra graças às citações de Sexto Empírico e Simplício. Além desses autores, muitos outros contribuíram com citações em suas obras para a manutenção de partes importantes do poema, tais como Platão, Aristóteles, Plutarco etc.

Além da impossibilidade em reconstituir o poema de modo integral, também a vida de Parmênides oferece poucos dados documentados por seus contemporâneos. Deste modo, segue-se aqui a análise de Cordero (2011), que assume como referência os escritos de Diógenes Laértio para posicionar a fase mais produtiva de Parmênides por volta de 504 e 501 a.C., período no qual ocorreu a $69^{a}$ Olimpiada. Não se pretende avaliar as questões relacionadas à polêmica data de nascimento do autor, ${ }^{3}$ por se tratar de um problema que nada interfere na análise pretendida, que é dependente apenas da constatação do período no qual Parmênides desenvolveu seu pensamento. De posse de tal informação já se pode compreender as influências sobre o filósofo, seu objetivo e a natureza de suas obras.

Para fins de estudo, serão apresentadas algumas passagens retiradas do poema, com o objetivo de constatar a presença de características do pensamento filosófico-científico, em ascensão no século VI a.C. Na sequência deste trabalho, será apresentado o fragmento 1 do Poema de Parmênides, primeiro em na sua lingua original (o dialeto jônico), e, logo em seguida, em uma tradução efetuada para a língua portuguesa. ${ }^{4} \mathrm{~A}$ análise do conteúdo deste trecho será feita e depois serão expostos os fragmentos 6 e 8, com as respectivas comparações desses dois últimos com a linguagem simbólica fortemente presente no primeiro fragmento.

\footnotetext{
${ }^{1}$ Cordero (2005, p. 27), quando fala a respeito da reconstituição do poema, critica o uso da palavra fragmento para fazer menção às partes restantes do poema, dizendo que seria mais apropriado tratá-las por citações.

2 A última edição crítica dos fragmentos do poema de Parmênides foi empreendida por Néstor Cordero, que se manteve fiel à tradição manuscrita, propondo uma sóbria tradução baseada em sua própria edição. (2005, p. 21122).

${ }^{3}$ A polêmica é instaurada por causa das diferenças de dados entre Platão e Diógenes de Laértio. Para debate sobre a questão ver Cordero (2005, pp. 19-22).

${ }_{4}$ O texto grego pertence à edição crítica de Cordero (2005, p. 211-2) e a tradução a Nogueira (2013, p. 90-92).
} 
Poema de Parmênides

Fragmento 1

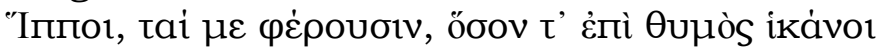

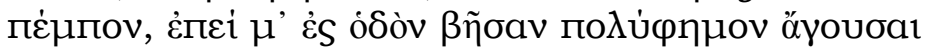

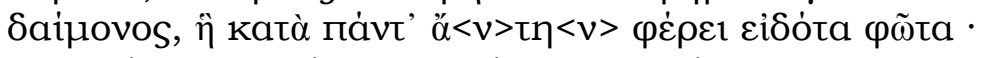

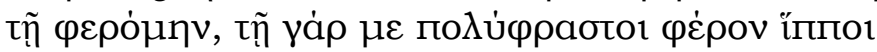

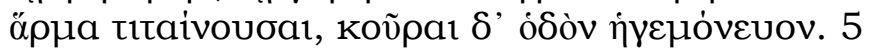

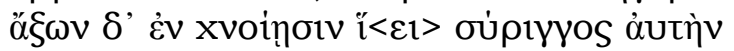

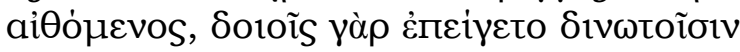

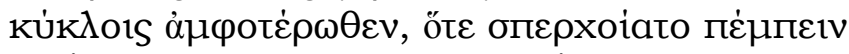

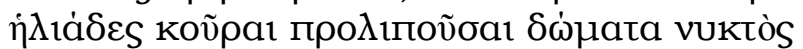

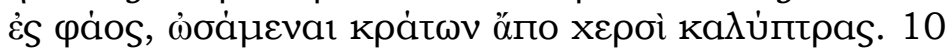

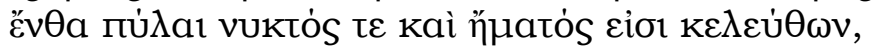

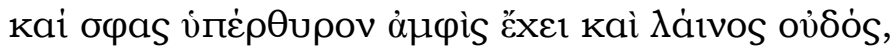

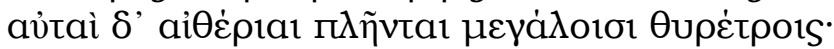

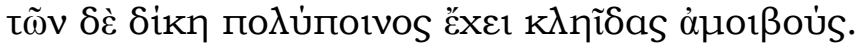

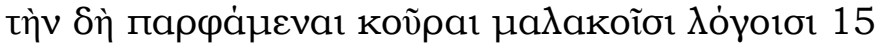

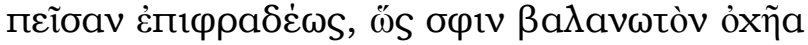

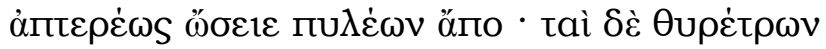

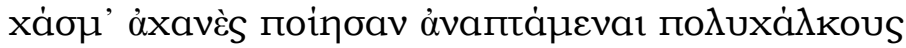

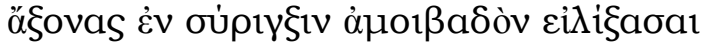

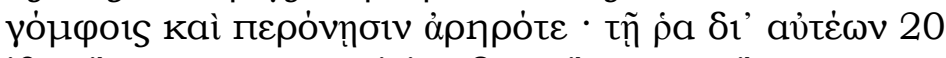

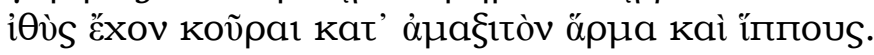

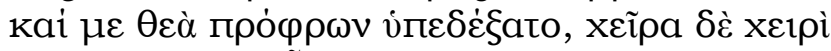

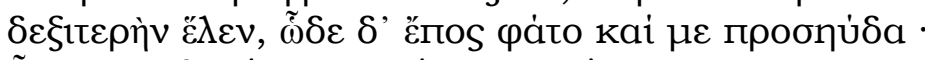

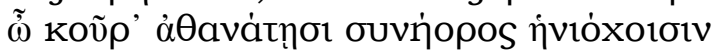

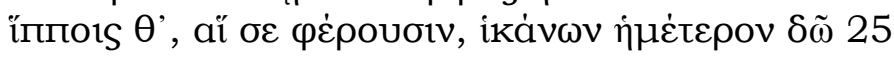

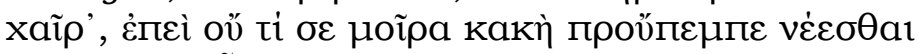

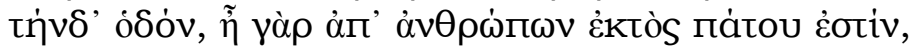

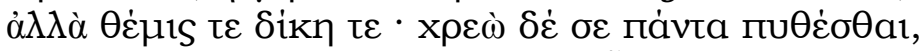

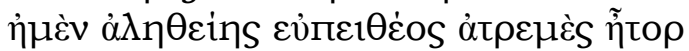

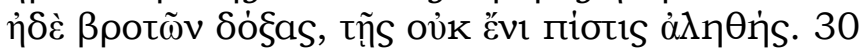

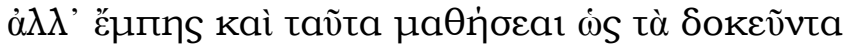

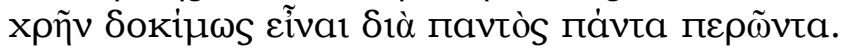
As éguas que me levam tanto quanto a vontade alcançava, Elas me enviavam, pois me conduziram guiando-me ao caminho pleno de vozes da divindade, ela que, por meio de tudo, leva por ali o homem sapiente.

Por ali eu era levado, pois por ali as éguas, muito sagazes, me levavam, ao arrastar o carro, e moças guiavam-me pelo caminho. 5

O eixo nas extremidades lança um grito de flauta, inflamando-se (pois era pressionado pelas duas rodas circulares, em ambos os lados), já que as moças filhas do sol se apressavam a enviar-me, após deixarem as moradas da noite, em direção à luz, afastando de suas cabeças, com as mãos, os véus, 10

lugar em que estão as portas das vias da noite e do dia, e uma viga superior as sustenta, em seus dois lados, e o umbral é de pedra Elas, etéreas, são preenchidas por grandes molduras, e a Justiça que muito pune detém as chaves que as alternam.

As moças conselheiras, então, com palavras afáveis, 15 
persuadiram-na com apuro, a fim de que para elas a tranca sujeita à abertura ela impelisse rapidamente para longe das portas; e elas produziram a imensa abertura de suas molduras, após se lançarem para fazer girar eixos plenos de bronze nos tubos ocos alternadamente, ajustados por pregos e pinos; por ali, exatamente através delas, 20

as moças retamente tinham o carro e os cavalos conforme era útil ao caminho. E a deusa acolheu-me benévola, tomou minha mão direita com sua mão, e assim falou este dito e o endereçou a mim:

"Ó rapaz, acompanhante de condutoras imortais, elas te levam com as éguas, alcançando tu a nossa morada, 25 salve, já que nenhum mau destino te enviou a traçar antes este caminho (pois certamente está fora da rota dos homens), mas a Lei e a Justiça! É necessário que tu busques conhecer tudo, tanto o coração, que não treme da verdade bem torneada, quanto as opiniões dos mortais, nas quais não existe verdadeira confiança. 30

Todavia também aprenderás isso: era necessário que os objetos considerados fossem comprovadamente penetrados totalmente através de tudo.

O texto acima citado, que é o prólogo completo do poema, ilustra a viagem de um homem aos domínios da deusa que o revelará "a verdade" (alétheia), por ele tão desejada. O Poema descreve detalhes da viagem, sendo esta realizada em uma carruagem flamejante puxada por éguas aladas, guiadas por moças imortais, filhas do sol. Chegando ao seu destino, o viajante se depara com uma porta que guarda as vias da noite e do dia e é vigiada pela Justiça, que detém sua chave. O autor descreve cada detalhe do formato da porta; desde o material do qual é feita, até os adornos que nele se encontram. As moças pedem gentilmente à Justiça que abra a porta, e são prontamente atendidas, dando assim passagem para que o viajante entre no dominio dos deuses, lugar incomum para os homens. Este fragmento termina com a deusa dirigindo-se diretamente ao viajante dizendo que irá lhe revelar "a verdade", que pode ser entendida como o conteúdo do ser e do não-ser compreendido em outras passagens do poema.

No prólogo, há o predomínio de imagens simbólicas que visam a sustentar a ideia filosófica de busca pela verdade, com a presença de várias ações e personagens, conforme atesta Nogueira (2013, p.90):

Para formar imagens em seu poema, Parmênides faz largo uso de vocabulário referente a seres e objetos retirados de um cotidiano específico, que recebem seu sentido do contexto de enunciação do tempo do filósofo.

A citação acima faz referência ao uso da simbologia mítica, que era uma linguagem à qual o público estava acostumado, para possivelmente tornar a escritura do poema mais próxima de um modelo até então muito comum. É preciso lembrar que nos séculos anteriores havia a épica (VIII a.C.) e a poesia lírica (VII a.C.), e, assim, esse gêneros são tomados por Parmênides como modelos didáticos para a divulgação de sua filosofia, sendo, assim, construtores de informações plausiveis de serem compreendidos por receptores que compartilham um mesmo contexto de enunciação da Antiguidade helênica. É importante salientar que a terminologia contexto de enunciação que o helenista cita pertence à linha 
pragmática de análise do discurso e diz respeito à própria ambientação que, como o nome indica, produz certo enunciado, seja oral ou escrito.

O tipo de construção na qual o poeta recebe o conhecimento de uma entidade superior e transmite essa mesma verdade para o ouvinte é característico dos poemas épicos representados principalmente pela Ilíada e pela Odisseia de Homero. Poderá ser observado na sequência deste trabalho que o proêmio em nada se parece com as outras partes restantes do poema, pois nelas o autor se dedica a discussões completamente abstratas sobre a existência e a não-existência (o ser e o não-ser).

Torna-se necessário fazer algumas considerações sobre a palavra "verdade" a qual se está a todo tempo se citando e que aparece no Poema para qualificar todo o discurso que a deusa fará para o viajante. No dicionário grego-português organizado por Malhadas, Dezotti e Neves encontra-se a seguinte tradução:

$\dot{\alpha} \lambda \dot{n} \theta \varepsilon ı$ (alétheia): 1.verdade; 2.sinceridade, franqueza; 3.veracidade oracular, 4.realidade.

Dentre os quatro conceitos apresentados no dicionário consultado, a que mais interessa para a análise pretendida do Poema de Parmênides é a terceira definição. A "veracidade oracular" aparece num contexto específico da história da Grécia Antiga, anterior a Parmênides, e no qual predominavam os poemas épicos. Estas composições pertencem a uma tradição oral, antes ainda da escrita, e eram apresentadas ao público por meio de cantos. Etimologicamente, o termo alétheia possui um valor imagético muito significativo, pois, sendo formado pelo alfa privativo associado ao substantivo léthe, esquecimento, apresenta a ideia de que a verdade seria uma ausência de esquecimento, algo que se mantém pela sua importância na lembrança, e, assim, torna-se completamente lógica a expressão dessa verdade por meio da épica, com seu conteúdo expresso ao poeta pela força da musa, a memória de tudo aquilo que necessita ser lembrado (vale registrar que, na mitologia grega, as musas são filhas de Mnemosýne, Memória).

Uma das características marcantes dos poemas épicos era a referência aos deuses e às musas, sendo que essas últimas eram as responsáveis por revelar a verdade ao poeta, entendido como divino porque atuava como intermediário entre as divindades e os demais mortais, que, diferentemente dos poetas, eram incapazes de se conectar às divindades. Deste modo, como afirma Lopes (1996, p. 155), podese observar que "os fatos contados na poesia épica não o são a partir da memória humana e da invenção, mas da memória divina, definitiva e inquestionável, que tanto se revela enigmática como clara e exata".

Segundo Cordero (2011, p. 92), a referência a uma verdade absoluta e incontestável revelada por uma divindade, além da familiaridade das pessoas com os poemas épicos, pode explicar alguns dos motivos pelos quais o poeta-filósofo Parmênides tenha escolhido o formato de poema para a sua composição.

Nos demais fragmentos, o simbolismo da linguagem mítica e os seres fantásticos são raramente citados. Apesar de o texto ter sido composto na primeira pessoa do singular e configurar a verdade transmitida pela deusa ao homem que vai ao seu encontro, a deusa em si e as demais personagens que têm uma presença muito forte no Proêmio, diminuem consideravelmente de atuação nas partes restantes do poema que sobreviveram ao tempo, que não possuem quase nada do conteúdo imagético que domina o proêmio.

$\mathrm{Na}$ intenção de exemplificar o pensamento filosófico contido no Poema de Parmênides e compará-lo com a linguagem simbólica usada no Proêmio, apresentam-se três fragmentos e alguns versos de outro mais extenso, com o intuito de fazer uma análise voltada para as partes que vêm depois do proêmio. Por meio das passagens selecionadas, é possivel perceber que Parmênides expõe um de seus 
pensamentos filosóficos mais fundamentais: a preocupação em argumentar e comprovar que "existem coisas".

$\mathrm{Na}$ sequência será apresentado o fragmento $2^{5}$, com sua tradução para a língua portuguesa, além de alguns versos selecionados dos fragmentos $6^{6}$ e $8^{7}$, também traduzidos.

\section{Fragmento 2}

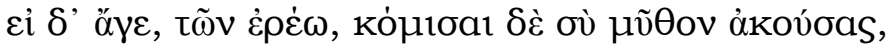

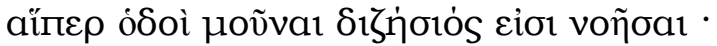

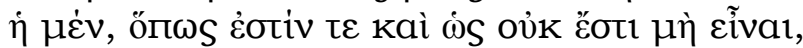

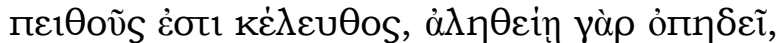

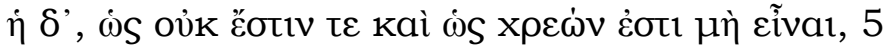

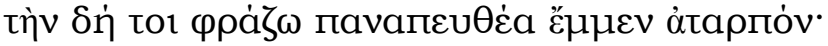

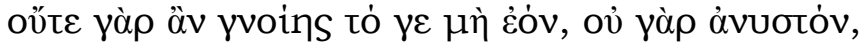

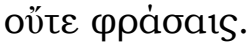

Anda dai e eu te direi (e tu trata de levares as minhas palavras contigo, depois de as teres escutado) os únicos caminhos da investigação em que importa pensar.

Um, [aquilo] que é e que [lhe] é impossivel não ser, é a via da Persuasão (por ser companheira da Verdade); o outro, [aquilo] que não é e que forçoso se torna que não exista, 5 esse te declaro eu que é uma vereda totalmente indiscernivel, pois não poderás conhecer o que não é - tal não é possivel nem exprimi-lo por palavras.

O texto acima dá continuidade ao Proêmio e apresenta a fala da deusa para o viajante que está em sua jornada pela busca do conhecimento. A deusa fala sobre o caminho da Verdade, no qual se admite a existência de "coisas", ou "entes" (tá ónta). A deusa afirma que este é o caminho da persuasão, pois é forçoso que existam coisas, justificando que a não existência não pode ser concebida, uma vez que não se pode afirmar que o nada é algo. Nessa, seu pensamento, Parmênides se apresenta como o iniciador da argumentação lógica em filosofia.

Uma das sutilezas do pensamento do poeta-filósofo está na própria escrita do poema. Parmênides usa o verbo ser sem apresentar um sujeito para esse verbo, forçando que o leitor reflita sobre esse sujeito, esse ente, ou seja, decifrar quem é aquele que é. Essa questão é resolvida na tradução usando os termos aquilo entre colchetes, o que reforça a ausência deste termo no texto original e sua inserção na tradução possivelmente para que a mesma se faça mais compreensivel.

A dissertação sobre o que é (ser) e o que não é (não-ser) aparece também nos dois primeiros versos do fragmento 6 , que acrescenta elementos à discussão sobre a existência e não existência, de modo a reforçar os argumentos sobre o caminho da Verdade.

\footnotetext{
${ }^{5}$ O texto grego foi retirado de Coxon (2009, p.57) e a tradução de Kirk (2010, p.255), vertida para o português por Carlos Alberto Louro Fonseca.

6 O texto grego foi retirado de Coxon (2009, p.59) e a tradução de Kirk (2010, p.257), ), vertida para o português por Carlos Alberto Louro Fonseca.

7 O texto em grego foi retirado de Coxon $(2009$, p.69, 71) e a tradução de Kirk (2010, p.259-260), ), vertida para o português por Carlos Alberto Louro Fonseca.
} 


\author{
Fragmento 6

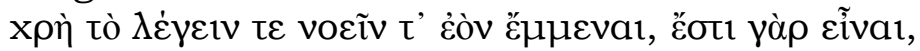

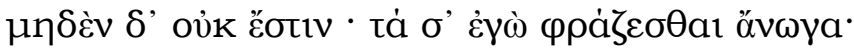

Forçoso é que o que se pode dizer e pensar seja; pois the é dado ser, e não ao que nada é. Isto te ordeno que ponderes;

Os versos acima citados apresentam uma novidade em relação aos outros que foram expostos anteriormente: o autor assume que as ações de pensar e falar atuam apenas sobre coisas existentes, de modo que sobre as coisas inexistentes não se pode pensar ou falar. O ato de pensar ou falar sobre alguma coisa é condição necessária e suficiente para que esta coisa exista.

$\mathrm{E}$, finalmente, os trechos do fragmento 8 que selecionamos para análise completam o pensamento sobre a existência das coisas por meio da reflexão sobre o surgimento, ou criação, e o ocaso dos entes. Tal aspecto pode ser observado abaixo:

\title{
Fragmento 8
}

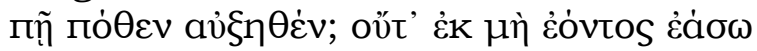

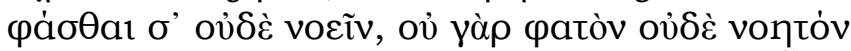

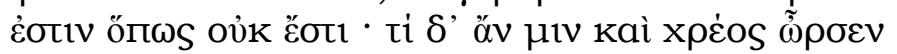

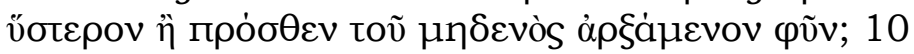

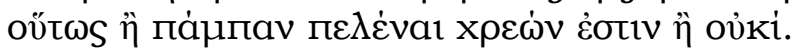

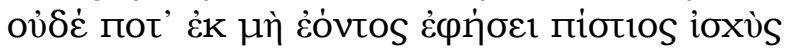

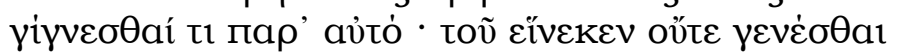

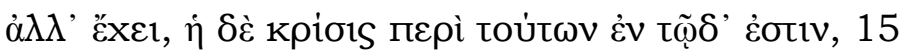

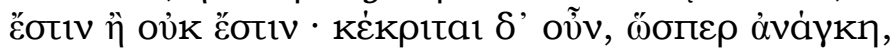

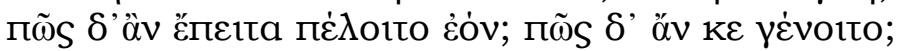

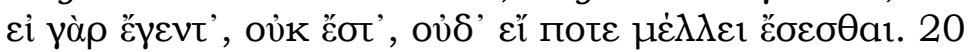

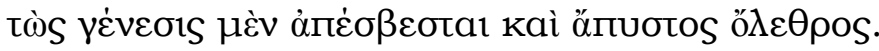

Como e donde cresceu? Não te permitirei que

digas ou que penses a partir do que não é: pois é indizivel e impensável o que não é; e que necessidade o teria levado

a surgir mais tarde, em vez de mais cedo, se viesse do nada? 10

Assim, força é ou que seja inteiramente, ou absolutamente nada. Nem a força da persuasão consentirá que, junto do que é, algo possa surgir alguma vez do que não é.

E a decisão acerca disto reside no seguinte: 15

é ou não é. Mas decidido está, de fato, como é necessário,

E como poderia ser no futuro o que é? Como poderia gerar-se? É que, se se gerou, não é: nem é, se alguma vez vier a ser no futuro. 20

Assim se extingue a geração, e a destruição.

O trecho acima citado se refere a versos do fragmento 8, que foram cuidadosamente selecionados para no intuito de corroborar a análise feita por nós a partir do fragmento 2 e partes do fragmento 6.

Neste fragmento, diferente dos outros dois analisados anteriormente, são citados elementos míticos e os versos dedicados a eles não foram citados acima apenas por uma questão de comodidade, pois o pensamento filosófico de Parmênides aparece bem representado nos versos que escolhemos para análise. 
Neste trecho há uma reflexão profunda sobre a integridade das coisas, tendo como principal argumento a impossibilidade de criação ou dissolução das coisas. $\mathrm{O}$ autor defende a necessidade da existência ou não existência como propriedade inerente às coisas, ou seja, algo não pode surgir do nada, assim como também não pode ser reduzido a nada. Ele defende que a essência das coisas não pode ser corrompida, surgindo do nada ou tornando-se nada; não têm início ou fim, simplesmente são (existem). Algo que existe sempre existiu e não se extinguirá. Neste pensamento de existência e não existência, afirmando de o segundo caso não pode ser concebido, ou seja, em termos bem simples; o nada não existe por não poder ser sequer pensado. O curto e enigmático fragmento 3, por fim, sintetiza, de maneira perfeita esse caráter de que só o que é pode ser pensado:

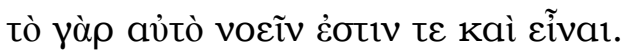

pois o mesmo é (a) pensar e também ser.

Ao relacionar de maneira tão próxima os atos de pensar e ser, Parmênides os torna interdependentes, fato reforçado pelo uso do pronome substantivado no neutro tò autó, o mesmo. Se a mesma coisa é pensar e ser, então, apenas o que é pode ser pensado, pois o que não pode ser pensado não pode ter o estatuto de ser, uma vez que não pode nem mesmo ser concebido pela mente. Se algo é alguma coisa, então, esse algo tem que ser, e, sendo, pode ser pensado, caso contrário não poderia. Assim, forma-se o argumento lógico de Parmênides. Portanto a mesma coisa é pensar e ser, pois não haveria ser sem pensamento e nem pensamento sem ser.

A reflexão do poeta sobre o ser e o não-ser, que resulta na dissertação sobre a natureza das coisas, sobre a impossibilidade da criação de elementos a partir do nada e sobre a incorruptibilidade das coisas, aparece a partir do fragmento 2 e reforça a ideia de que o fragmento 1, ou Proêmio, seja uma preparação, com uma linguagem mais familiar, típica dos poemas épicos, para o leitor transpor um modelo literário conhecido e ser capaz de entrar em contato com uma estrutura de pensamento direcionado para um pensamento filosófico e não mais para o universo de seres mitológicos e grandes feitos heroicos.

Segundo Cordeiro (2011), apesar de não ter sido citado até os escritos de Platão, Parmênides talvez tenham servido de inspiração para alguns pensadores de sua época e pouco posteriores. Os atomistas, contrariando o pensamento de Parmênides, conforme de praxe ocorre com um pensamento tipicamente filosóficocientífico, 8 afirmam que o nada também é e que a realidade é inteligível (só pelo pensar é possivel chegar a essa conclusão), uma vez que o ser humano tem espaços vazios entre cada átomo. 9 Posteriormente, Platão se interessa justamente em afirmar a existência metafísica das ideias, o verdadeiro real por trás das aparências percebidas pelos sentidos, o que não deixa de ser um caminho a ser seguido e uma apropriação de Parmênides, mesmo que por meio de uma interpretação de sua filosofia. ${ }^{10}$

Ainda há muito que pesquisar sobre Parmênides e outros pensadores que maravilham os homens com suas ideias filosóficas, que ajudam a pensar o real ao

\footnotetext{
8 O pensamento mítico não se presta a questionamentos. Ou o indivíduo faz parte de uma comunidade e aceita o seu conteúdo ou não participa dela e tal conteúdo é estranho para si.

9 Se o homem fosse um todo, não seria ele composto por vários átomos, unidades indivisiveis, e, assim, como não é inteiriço, possui espaços vazios entre si. Portanto, no atomismo, o nada também é.

10 Os estudos empreendidos por Cordero tendem a colocar Parmênides no seu papel de pré-socrático, e, assim, o estudioso se afasta da interpretação heidggeriana que dominou o século XX e que toma Parmênides como metafísico, o que seria anacrônico na interpretação de Cordero. Nesse sentido, o Parmênides de Heidegger é baseado na interpretação platônica de que o verdadeiro ser se encontra por trás da aparência, mas Parmênides nunca utilizou a palavra eikasia, aparência, e sim o termo dóxa, opinião, sendo que, ao que parece, o ser para Parmênides é simplesmente o fato de ser, o que se dá na phýsis, natureza, e não fora dela, não em um mundo metafisico.
} 
redor do ser humano e o próprio homem em si. É digno de nota o interesse em observar, em um tempo tão antigo, pensamentos originários que, tentando se desvencilhar das crenças e do mito buscam desvendar alguns mistérios da natureza, que antes eram atribuídos à vontade dos deuses. Ao se consolidar o pensamento filosófico-científico, o homem ocupa mais um espaço, em que atua em sua realidade para abandonar quase por inteiro o status de vitima da vontade de uma entidade superior.

\section{Referências bibliográficas:}

BARNES, Jonathan. Filósofos pré-socráticos. São Paulo: Martins Fontes, 1997.

CASERTANO, Giovanni. Os pré-socráticos. Ediçoes Loyola: São Paulo, 2011.

CORDERO, Néstor Luis. A invenção da filosofia. SP: Odysseus, 2011.

. Siendo, se es: la tesis de Parménides. Buenos Aires: Biblos, 2005.

- En Parménides, 'tertium non datur'. In Acerca do Poema de Parmênides:Estudos apresentados no I Simpósio Internacional OUSIA de Estudos Clássicos (Fernando Santoro, Henrique Cairus e Tatiana Ribeiro, organizadores). Rio de Janeiro: Beco do Azougue Editorial Ltda., 2009.

COXON, A. H. The Fragments of Parmenides: A Critical Text with Introduction and Translation, the Ancient Testimonia and a Commentary. Las Vegas: Parmenides Publishing, 2009

HOMERO. Míada. Trad. Carlos Alberto Nunes. São Paulo: Ediouro, 2009.

HOMERO. Odisséia. Trad. Carlos Alberto Nunes. São Paulo: Ediouro, 2009.

HEIDEGGER, Martin. Parmênides. Petrópolis: Ed. Vozes; Bragança Paulista: Ed. Universitária São Francisco, 2008.

KAHN, Charles. Algumas questões controversas na interpretação de Parmênides. In Acerca do Poema de Parmênides: Estudos apresentados no I Simpósio Internacional OUSIA de Estudos Clássicos (Fernando Santoro, Henrique Cairus e Tatiana Ribeiro, organizadores). Rio de Janeiro: Beco do Azougue Editorial Ltda., 2009.

LEGRAND, Gérard.Os Pré-Socráticos. Rio de Janeiro: Jorge Zahar Ed., 1991.

LUCE, John Victor. Curso de Filosofia Grega: do século VI a.C. ao século III d.C. Rio de Janeiro: Jorge Zahar Ed., 1994.

LOPES, Silvina Rodrigues. A Poesia, Memória Excessiva. Revista da Faculdade de Ciências Sociais e Humanas, n.9, Lisboa, Edições Colibri, 1996, p.155-161.

MACIEL JÚNIOR, Auterives. Pré-Socráticos, A Invenção da Razão. São Paulo: Odysseus, 2007.

MALHADAS, Daisi, DEZOTTI, Maria Celeste \& NEVES, Maria Helena de Moura (equipe de coordenação). Dicionário Português-Grego. São Paulo: Ateliê Editorial, 2006, 2007, 2008, 2009, 2010. 5 vol. 
MARCONDES, Danilo. Iniciação à história da filosofia: dos pré-socráticos a Wittgenstein. Rio de Janeiro: Jorge Zahar Ed., 1997.

NOGUEIRA, Ricardo de Souza. As Imagens do saber no prólogo do poema Da Natureza. In Caliope Presença Clássica $n^{o}$ 26, Rio de Janeiro: Programa de Pósgraduação em Letras Clássicas da UFRJ, 2013.

KIRK, G. S.; RAVEN, J. E.; SCHOFIELD, M . Os Filósofos Pré-Socráticos: História Crítica com Seleção de Textos, 7 ed. Trad. Carlos Alberto Louro Fonseca. Lisboa: Fundação Calouste Gulbenkian, 2010. Disponivel em <https://martaluzie.files.wordpress.com/2014/09/kirk-raven-schofield-osfilc3b3sofos-prc3a9-socrc3a1ticos.pdf>, acesso em 08/12/2017.

PARMÊNIDES, XENÓFANES (fragmentos). Filósofos épicos 1. Edição do texto grego, revisão e comentários por Fernando Santoro, com revisão científica de Néstor Cordero. Rio de Janeiro: Hexis Editora, 2011.

VERNANT, Jean Pierre. As origens do pensamento grego. Rio de Janeiro: Bertrand Brasil, 2000. 